\title{
Growth of tropical grasses in Oxisol contaminated by nickel
}

\author{
Enilson de Barros Silva ${ }^{1 *}$, Francisco Vagner Pereira de Souza ${ }^{1}$, Paulo Henrique Grazziotti ${ }^{1}$,
} Luīs Reynaldo Ferracciú Alleoni ${ }^{2}$, Bārbara Olinda Nardis ${ }^{1}$, and Evander Alves Ferreira ${ }^{1}$

\section{ABSTRACT}

Soil pollution by heavy metals has increased worldwide and the search for plants that can be used to remediate polluted areas is an interesting alternative. The aim of this study was to evaluate the tolerance of tropical grasses to Ni and its availability for the Mehlich 1, DTPA, and USEPA 3051 and 3052 extraction methods in Nicontaminated Oxisol. Megathyrsus maximus (Jacq.) B.K. Simon \& S.W.L. Jacobs 'Aruana' and 'Tanzania', Urochloa brizantha (Hochst. ex A. Rich.) R.D. Webster 'Xaraés' and 'Marandu', and Urochloa decumbens (Stapf) R.D. Webster 'Basilisk' were grown for $90 \mathrm{~d}$ in a Typic Hapludox (Oxisol) after adding 20, 40, and $120 \mathrm{mg} \mathrm{Ni} \mathrm{kg}^{-1}$ to the soil. Tropical grasses showed a positive response to the application of $\mathrm{Ni}$ doses. The order of decreasing tolerance of tropical grasses to $\mathrm{Ni}$ in the soil was: 'Basilisk' $>$ 'Xaraés' > 'Marandu' > 'Aruana' > 'Tanzania' based on the critical toxicity dose. Nickel concentration and accumulation increased with increasing soil $\mathrm{Ni}$ doses in all the tropical grasses. Mehlich 1, DTPA, USEPA 3051, and USEPA $3052 \mathrm{Ni}$ extraction methods in the soil are efficient to diagnose $\mathrm{Ni}$ availability in tropical grasses.

Key words: Bioremediation, critical level, extractor, heavy metals, phytoextraction.

${ }^{1}$ Universidade Federal dos Vales do Jequitinhonha e Mucuri (UFVJM), Faculdade de Ciências Agrárias, Campus JK, Rodovia MGT 367, 5000 Diamantina, Minas Gerais, Brasil.

*Corresponding author (ebsilva@ufvjm.edu.br).

${ }^{2}$ Universidade de São Paulo, Escola Superior de Agricultura Luiz de Queiroz (USP/ESALQ), Avenida Pádua Dias, 11 Piracicaba, São Paulo, Brasil.

Received: 17 June 2016.

Accepted: 19 April 2017.

doi:10.4067/S0718-58392017000300273

\section{INTRODUCTION}

The contamination of soil and water by toxic substances, such as heavy metals, has become more and more frequent. The main activities that have increased the levels of heavy metals in soils are industrial, such as the chemical and metallurgical industry, paper mills, tanneries, textile mills, and waste disposal sites (Tchounwou et al., 2012).

Nickel is a heavy metal that is constantly deposited in the soil through anthropogenic activities and pollution by this element has become a global problem. Although $\mathrm{Ni}$ is an essential element for plants (López and Magnitski, 2011; Fabiano et al., 2015), high levels of this metal in the environment can cause phytotoxicity (Kovácik et al., 2009) and even reach the animal and human food chain (Rodak et al., 2015). In general, critical toxicity levels are $10 \mathrm{mg} \mathrm{kg}^{-1} \mathrm{DM}$ in sensitive species, $50 \mathrm{mg} \mathrm{kg}^{1} \mathrm{DM}$ in moderately tolerant species, $100 \mathrm{mg} \mathrm{kg}^{-1} \mathrm{DM}$ in tolerant species (Yusuf et al., 2011; Hussain et al., 2013; Matraszek et al., 2016), and 1000 $\mathrm{mg} \mathrm{kg}{ }^{-1} \mathrm{DM}$ in Ni hyperaccumulator plants, such as the Alyssum and Thlaspi species (Yusuf et al., 2011; Leitenmaier and Küpper, 2013; Matraszek et al., 2016).

Nickel availability is related to soil and plant characteristics. The factors that influence soil $\mathrm{Ni}$ phytoavailability are $\mathrm{pH}$, redox potential, texture, concentration and types of silicate minerals and $\mathrm{Fe}, \mathrm{Al}$ and $\mathrm{Mn}$ oxides, organic matter concentration, presence of other heavy metals, and microbial activity (Tchounwou et al., 2012). The reference value of soil quality for agricultural intervention indicated by the São Paulo State Environmental Agency (2005) is $13 \mathrm{mg} \mathrm{Ni} \mathrm{kg}^{-1}$ and the National Environmental Council of Brazil (2009) establishes a reference quality value of $30 \mathrm{mg} \mathrm{kg}^{-1}$ to ensure soil quality to prevent problems in food grown in Ni-contaminated soils; both these values are for total $\mathrm{Ni}$ extraction.

There have been several solutions to extract bioavailable concentrations of heavy metals in soil, such as diethylenetriaminepentaacetic acid (DTPA), Mehlich-1, and acid mixture (Rodak et al., 2015); some of these have been used in laboratories to evaluate the availability of various cationic micronutrients. The United States Environmental Protection Agency recommends determining the pseudo total present in the sample concentration (USEPA, 2007) to monitor soil pollution by heavy metals. Conventionally, this analysis requires digestion with hydrofluoric acid (HF) together with other strong acids (Nascimento et al., 2014). However, the use of HF in routine laboratories is not recommended because this reagent is difficult to handle. For 
this, strong acids have been used that are not part of the routine chemical soil analysis for fertility purposes; they do not always extract concentrations of elements correlated with levels absorbed by plants. Correlations between soil $\mathrm{Ni}$ concentration extracted by several extractors and the concentration accumulated by some plants have defined the most efficient extractors to predict the phytoavailability of this element (Berton et al., 2006; Chang et al., 2014; Rodak et al., 2015).

Plants that accumulate high amounts of $\mathrm{Ni}$ may be suitable for phytoremediation. Plants that are ideal for phytoremediation must be able to tolerate, grow, and accumulate metals in the climate and soil conditions of the area to be remediated; plants must grow rapidly and be easily harvested (Jabeen et al., 2009). Tropical grasses are generally undemanding with high biomass production and rapid growth.

In this context, the objective of this study was to evaluate the tolerance of tropical grasses to $\mathrm{Ni}$ and determine its availability in the soil using the Mehlich 1, DTPA, and USEPA 3051 and 3052 extraction methods in Nicontaminated Oxisol.

\section{MATERIALS AND METHODS}

The experiment was conducted in a greenhouse in Diamantina ( $18^{\circ} 14^{\prime} \mathrm{S}, 43^{\circ} 36^{\prime} \mathrm{W} ; 1.250 \mathrm{~m}$ a.s.1.), Minas Gerais, Brazil, with samples of a Typic Hapludox (Oxisol) classified according to Soil Taxonomy (Soil Survey Staff, 2010) collected in the Bw horizon at $0.80 \mathrm{~m}$. The soil was ground into small particles, air-dried, and passed through a $5.0 \mathrm{~mm}$ sieve. A subsample was taken and passed through a $2.0 \mathrm{~mm}$ sieve, thus forming thin air-dried soil for chemical and soil texture analysis (Embrapa, 1997) (Table 1). The $\mathrm{pH}$ was measured potentiometrically (soil:water 1:2.5, v/v); $\mathrm{P}$ and $\mathrm{K}$ were extracted by Mehlich-1 and determined by colorimetry $(\mathrm{P})$ and flame photometry $(\mathrm{K})$, while $\mathrm{Ca}, \mathrm{Mg}$, and $\mathrm{Al}$ were extracted by $1 \mathrm{~mol} \mathrm{~L}^{-1} \mathrm{KCl}$ and determined by flame atomic absorption spectrophotometry $(\mathrm{Ca}$ and $\mathrm{Mg}$ ) and titration with $0.025 \mathrm{~mol} \mathrm{~L}^{-1} \mathrm{NaOH}(\mathrm{Al})$. Acidity $(\mathrm{H}+$ $\mathrm{Al}$ ) was extracted with $0.5 \mathrm{~mol} \mathrm{~L}^{-1}$ calcium acetate buffered at $\mathrm{pH} 7.0$ and quantified by titration with $0.025 \mathrm{~mol} \mathrm{~L}^{-1}$ $\mathrm{NaOH}$. Organic $\mathrm{C}$ was determined by the Walkley-Black method. Base saturation values were calculated using the following equation: Base saturation $(\mathrm{V} \%)=(\Sigma \mathrm{Ca}, \mathrm{Mg}, \mathrm{K}) /$ $(\mathrm{CEC}) \times 100$. The values of $\mathrm{K}, \mathrm{Ca}, \mathrm{Mg}, \mathrm{H}+\mathrm{Al}$, and cation exchange capacity $(\mathrm{CEC}=\Sigma \mathrm{K}, \mathrm{Ca}, \mathrm{Mg}, \mathrm{H}+\mathrm{Al})$ were expressed in $\mathrm{mmol}_{\mathrm{c}} \mathrm{kg}^{-1}$. Soil physical fractionation was performed by the densimeter method.

Soil Ni concentration was determined prior to the application of the Ni doses by Mehlich-1 (Embrapa, 1997) and diethylene-triaminepentaacetic acid-DTPA at $\mathrm{pH} 7.3$ (Zhang et al., 2010). Soil Ni concentration was defined by the USEPA 3051 method and microwave oven digestion with concentrated $\mathrm{HNO}_{3}(65 \%)$ of analytical purity (USEPA, 2007); total soil concentration was determined by the USEPA 3052 method by microwave oven digestion with
$\mathrm{H}_{2} \mathrm{O}_{2}+\mathrm{HNO}_{3}+\mathrm{HF}$ in addition to $\mathrm{H}_{3} \mathrm{BO}_{3}$ (USEPA, 2007) (Table 1).

Liming was carried out with dolomitic limestone and $90 \%$ effective calcium carbonate equivalent in $3.2 \mathrm{Mg} \mathrm{ha}^{-1}$ to raise the base saturation to $45 \%$. The lime requirement (LR) was calculated as LR $\left(\mathrm{Mg} \mathrm{ha}^{-1}\right)=\left(\mathrm{V}_{2}-\mathrm{V}_{1}\right) * \mathrm{CEC} / 100$ where $\mathrm{V}_{2}$ is the established base saturation (45\%) and $\mathrm{V}_{1}$ is the current base saturation (soil analysis). Soil remained incubated for $30 \mathrm{~d}$ under humid conditions equivalent to $60 \%$ of the total pore volume (TPV) controlled by daily weighing. Basic fertilization at planting was conducted as recommended in the pot experiment. Nutrients were applied as pure reagents and completely mixed into the soil. The applied doses consisted of $100 \mathrm{mg} \mathrm{N}\left(\mathrm{NH}_{4} \mathrm{H}_{2} \mathrm{PO}_{4}\right.$, $\left.\left(\mathrm{NH}_{4}\right)_{2} \mathrm{SO}_{4}\right), 200 \mathrm{mg} \mathrm{P}\left(\mathrm{NH}_{4} \mathrm{H}_{2} \mathrm{PO}_{4}\right), 150 \mathrm{mg} \mathrm{K}(\mathrm{KCl}), 50$ $\mathrm{mg} \mathrm{S}\left(\left(\mathrm{NH}_{4}\right)_{2} \mathrm{SO}_{4}\right), 1 \mathrm{mg} \mathrm{B}\left(\mathrm{H}_{3} \mathrm{BO}_{3}\right), 1.5 \mathrm{mg} \mathrm{Cu}\left(\mathrm{CuCl}_{2}\right), 5.0$ $\mathrm{mg} \mathrm{Fe}\left(\mathrm{FeSO}_{4} \cdot 7 \mathrm{H}_{2} \mathrm{O}\right.$ EDTA), $4.0 \mathrm{mg} \mathrm{Mn}\left(\mathrm{MnCl}_{2} \cdot \mathrm{H}_{2} \mathrm{O}\right)$, and $4 \mathrm{mg} \mathrm{Zn}\left(\mathrm{ZnCl}_{2}\right)$ per kg of soil incubated for $15 \mathrm{~d}$.

The design was completely randomized with four replicates for each forage grass. The study included five tropical grasses (Megathyrsus maximus (Jacq.) B.K. Simon \& S.W.L. Jacobs 'Aruana' and 'Tanzania', Urochloa brizantha (Hochst. ex A. Rich.) R.D. Webster 'Xaraés' and 'Marandu', and Urochloa decumbens (Stapf) R.D. Webster 'Basilisk') and four soil Ni doses $\left(0,20,40\right.$, and $\left.120 \mathrm{mg} \mathrm{kg}^{-1}\right)$ as pure nickel chloride for analysis. These Ni doses were based on the reference values of soil quality for agricultural intervention indicated for the State of São Paulo, Brazil (São Paulo State Environmental Agency, 2005). The heavy metal was applied after liming and basic fertilization at planting with soil incubation for another $15 \mathrm{~d}$ under humid conditions equivalent to $60 \%$ of TPV controlled by daily weighing.

Grasses were directly planted in plastic pots containing 4 $\mathrm{kg}$ soil. Soil moisture was maintained at approximately $60 \%$ $\mathrm{TPV}$, measured daily by weighing, and the mass completed with deionized water. Plants were thinned to one plant per pot after germination. Thirty days after thinning, plants were uniformly cut at $0.03 \mathrm{~m}$ from the stem base of each plant to initiate the evaluation period.

Plants were grown duirng three growth periods. After 30 $\mathrm{d}$ of the uniform cut, the first, second, and third evaluation

Table 1. Chemical and textural characterization before applying treatments.

\begin{tabular}{lcc}
\hline Property & Unit & Value \\
\hline $\mathrm{pH}_{\text {water }}^{\mathrm{a}}$ & - & 4.9 \\
$\mathrm{P}^{\mathrm{b}}$ & $\mathrm{mg} \mathrm{kg}^{-1}$ & 0.4 \\
$\mathrm{~K}^{\mathrm{b}}$ & $\mathrm{mmol}_{\mathrm{c}} \mathrm{kg}^{-1}$ & 0.2 \\
$\mathrm{Ca}^{\mathrm{c}}$ & $\mathrm{mmol}_{\mathrm{c}} \mathrm{kg}^{-1}$ & 7.0 \\
$\mathrm{Mg}^{\mathrm{c}}$ & $\mathrm{mmol}_{\mathrm{c}} \mathrm{kg}^{-1}$ & 1.0 \\
$\mathrm{Al}^{\mathrm{c}}$ & $\mathrm{mmol}_{\mathrm{c}} \mathrm{kg}^{-1}$ & 1.0 \\
$\mathrm{CEC}^{\mathrm{d}}$ & $\mathrm{mmol}_{\mathrm{c} \mathrm{kg}}$ & 81.0 \\
Organic C & $\mathrm{g} \mathrm{kg}^{-1}$ & 2.3 \\
$\mathrm{Ni}^{\mathrm{c}, \mathrm{e}, \mathrm{f}, \mathrm{g}}$ & $\mathrm{mg} \mathrm{kg}^{-1}$ & $<0.001$ \\
Sand & $\mathrm{g} \mathrm{kg}^{-1}$ & 730 \\
Loam & $\mathrm{g} \mathrm{kg}^{-1}$ & 70 \\
Clay & $\mathrm{g} \mathrm{kg}^{-1}$ & 200 \\
\hline
\end{tabular}

Soil:water 1:2.5; ${ }^{\mathrm{b}}$ Mehlich 1 extractor; ${ }^{\mathrm{C}} \mathrm{KCl} 1.0 \mathrm{~mol} \mathrm{~L}{ }^{-1}$ extractor; ${ }^{\mathrm{d} C a t i o n}-$ exchange capacity; ${ }^{\mathrm{e}}$ Diethylenetriaminepentaacetic acid (DTPA) extractor; fUSEPA 3051 method; gUSEPA 3052 method. 
cuts were performed at $30-\mathrm{d}$ intervals at $0.03 \mathrm{~m}$ from the stem base of the plants. Four cover fertilizations were applied with $50 \mathrm{mg} \mathrm{kg}^{-1}$ (urea) every $5 \mathrm{~d}$ after the uniform cut in the first growth period and five $\mathrm{N}$ fertilizations with $60 \mathrm{mg} \mathrm{kg}^{-1}$ (urea) for the last two grass growth periods. After the final cut, $90 \mathrm{~d}$ after the uniform cut, the stem $(0.03$ $\mathrm{m}$ remaining material that received the three shoot cuts) and roots were collected.

After the last shoot cut, $90 \mathrm{~d}$ after the uniform cut, the rest of the plant was collected: the stem base (connecting roots to shoots) and roots. All collected plant material was washed with tap water, distilled water, diluted detergent, distilled water again, $\mathrm{HCl}$ solution $0.1 \mathrm{~mol} \mathrm{~L}^{-1}$, and finally with deionized water to remove excess metal on the surface of the plant. Subsequently, the material was packed in paper bags and oven-dried with forced air circulation at $65^{\circ} \mathrm{C}$ for $72 \mathrm{~h}$.

After drying, the material was weighed on an analytical balance to measure the DM weight of shoots (sum of dry weight of the three cuts), stem base, and roots. Materials were ground and subjected to chemical analysis to determine $\mathrm{Ni}$ concentration and $\mathrm{Ni}$ doses in DM. The ground material was subjected to nitroperchloric digestion (nitric [65\% v/v] and perchloric acids [70\% v/v], 2:1; Merck, Darmstadt, Germany); the Ni concentration was determined by atomic absorption spectrometry in a graphite oven (AAnalyst 800, Perkin-Elmer, Waltham, Massachusetts, USA). Quality control of the Ni analysis was ensured by certified reference material (NIST SRM 1573a sheet tomato, National Institute of Standards and Technology [NIST], Standard Reference Material, Gaithersburg, Maryland, USA) and blank reagents. Based on the $\mathrm{Ni}$ concentration and DM of each part of the plant, cumulative $\mathrm{Ni}\left(\mu \mathrm{g} \mathrm{pot}^{-1}\right)$ was calculated by multiplying Ni concentration $\left(\mathrm{mg} \mathrm{g}^{-1}\right)$ by DM weight $(\mathrm{g})$.

After the last grass cut, soil samples were collected to quantify Ni concentration extracted with Mehlich-1 (Embrapa, 1997) and diethylene-triaminepentaacetic acid (DTPA) at pH 7.3 (Zhang et al., 2010). The Ni concentration was determined by the USEPA 3051 method bymicrowave oven digestion with concentrated $\mathrm{HNO}_{3}(65 \%)$ of analytical purity (USEPA, 2007); total soil concentration was defined by the USEPA 3052 method by microwave oven digestion with $\mathrm{HF}+\mathrm{HNO}_{3}+\mathrm{H}_{2} \mathrm{O}_{2}$ and subsequently adding $\mathrm{H}_{3} \mathrm{BO}_{3}$ (USEPA, 2007). The Ni concentration was determined by atomic absorption spectrometry with a graphite oven (Perkin-Elmer AAnalyst 800). Quality control of soil Ni analysis was carried out with certified soil samples (NIST SRM 2709 San Joaquin soil).

To determine the recommended dose (RD) and critical toxicity dose (CTD) of $\mathrm{Ni}$ for $90 \%$ maximum growth and $10 \%$ reduction in maximum growth of tropical grasses, a multivariate approach using the canonical variable joint analysis of variance of $\mathrm{Ni}$ doses was used for each tropical grass (Hair et al., 2009). With the canonical variable of greater self-worth, scores were obtained from the observation vector of each experimental unit of the studied grass growth variables, reducing them to a single value. These scores were subjected to joint analysis of variance and regression study of $\mathrm{Ni}$ doses. The regression equations were adjusted for the variables as a function of $\mathrm{Ni}$ doses after transforming scores related to the canonical variable for each grass. The soil $\mathrm{Ni}$ dose that provides the maximum canonical variable value for each tropical grass was calculated based on the first derivative of the regression equation, equaling zero. The RD corresponds to $90 \%$ of the maximum value of the scores related to the canonical variable of each tropical grass. The CTD caused a reduction of $10 \%$ in the value of the scores related to the canonical variable. The statistical analysis used the SAS for Windows software (SAS Institute, Cary, North Carolina, USA) by the PROG GLM and REG procedures.

The Ni critical range (CR) in the DM of shoots, stem base, and roots of the tropical grasses and $\mathrm{Ni}$ extracted by soil extraction methods (Mehlich-1, DTPA at pH 7.3, USEPA 3051, and USEPA 3052) was obtained by replacing the RD and CTD in the equations that relate to the Ni doses with these variables.

The Ni dose providing the maximum accumulation in shoots, stem base, and roots of tropical grasses is calculated based on the first derivative of the regression equation, equal to zero, for quadratic equations. For linear equations, it was the maximum $\mathrm{Ni}$ dose applied to the soil for the maximum $\mathrm{Ni}$ accumulation in shoots, stem base, and roots of tropical grasses.

Correlation studies were conducted to evaluate the relationships between $\mathrm{Ni}$ concentrations by soil extraction methods (Mehlich-1, DTPA at pH 7.3, USEPA 3051, and USEPA 3052) and $\mathrm{Ni}$ accumulation in shoot DM of the tropical grasses to define the best extractor to evaluate soil $\mathrm{Ni}$ availability.

\section{RESULTS AND DISCUSSION}

Multivariate analysis of variance (MANOVA) was performed to study the effect of four $\mathrm{Ni}$ doses on the variables DM weight of shoots (DWS), stem base (DWSB), and roots (DWR) of tropical grasses. Results of MANOVA showed that $\mathrm{Ni}$ doses were significant $(\mathrm{p}<0.01)$. The multivariate model of the first canonical variable was expressed as $(\mathrm{CV}$ $=0.1225 * \mathrm{DWS}+0.3239 * \mathrm{DWSB}+0.1344 * \mathrm{DWR}$ with eigenvalue $=95 \%$ ). This eigenvalue is satisfactory in studies using this technique. Tropical grass growth was affected by increasing $\mathrm{Ni}$ doses applied to the soil $(\mathrm{p}<0.01)$. There was increased growth of tropical grasses in the first soil $\mathrm{Ni}$ dose and a subsequent decrease when doses increased (Figure 1). The cultivars showed positive responses to increased Ni doses, exhibiting a square root response ('Aruana' and 'Xaraés') and/or cubic response ('Tanzania', 'Marandu', and 'Basilisk') to increased soil Ni doses (Figure 1).

The cultivars had different sensitivities to soil $\mathrm{Ni}$ concentration. Starting with the RD, soil Ni requirement in descending order was 'Marandu' > 'Basilisk' > 'Xaraés' $>$ 'Tanzania' > 'Aruana'. However, the descending order of tolerance to soil $\mathrm{Ni}$ based on the CTD was 'Basilisk' $>$ 'Xaraés' > 'Marandu' > 'Aruana' > 'Tanzania' (Figure 1). 
Figure 1. Relative score of the canonical variable of the multivariate analysis for tropical grasses depending on Ni doses applied to the soil and the recommended dose (RD) and critical toxicity dose (CTD) $90 \mathrm{~d}$ after the initial cut.

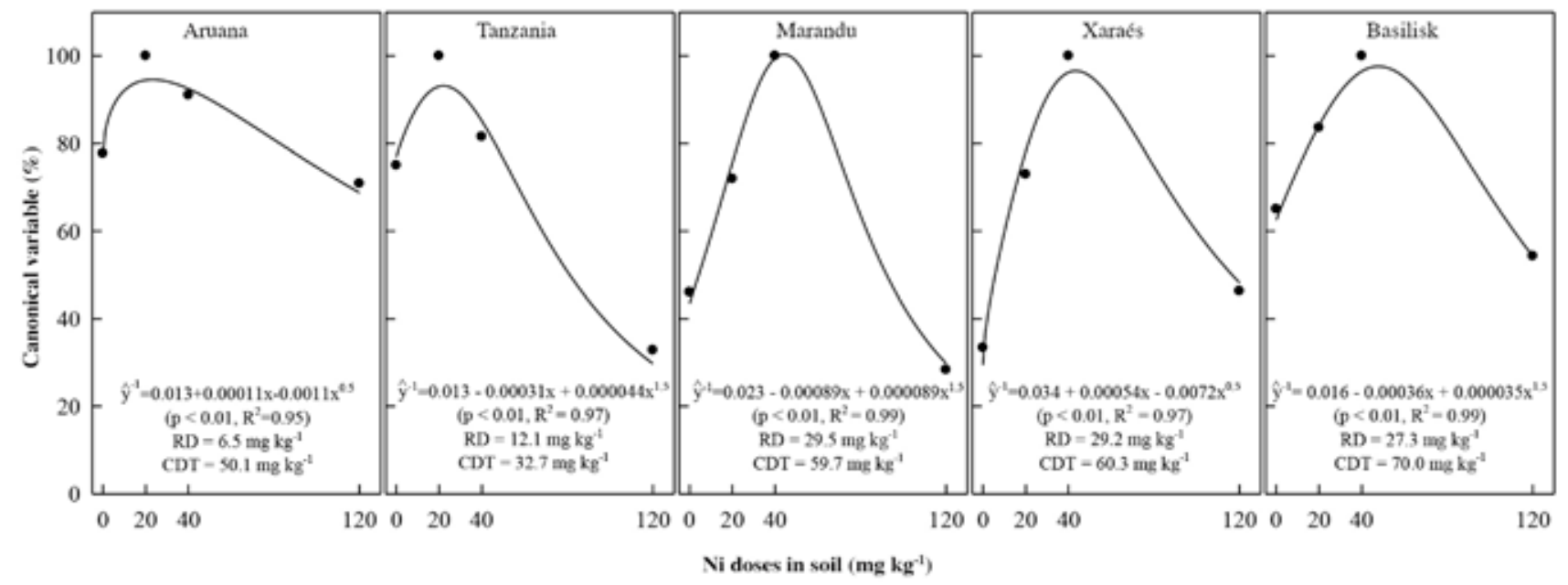

The positive responses of grasses to soil Ni corroborate the results found by Chen and Wong (2006), who evaluated the effect of increasing $\mathrm{Ni}$ concentration in acidic soil on Agropyron elongatum, noting that $\mathrm{Ni}$ slightly increased DM yields at a dose of $15 \mathrm{mg} \mathrm{kg}^{-1}$, but reduced plant DM at $\mathrm{Ni}$ doses higher than $100 \mathrm{mg} \mathrm{kg}^{-1}$ applied to the soil. Both results may be explained by the fact that $\mathrm{Ni}$, though it is toxic to plants in high doses, is an essential plant nutrient in acceptable doses (López and Magnitski, 2011; Fabiano et al., 2015) and can increase growth and yield. Nickel is essential for plants as a constituent of various metalloenzymes, including urease, some superoxide dismutases (SOD), NiFe hydrogenases, methyl coenzyme $M$ reductase, acetyl-coenzyme A synthase, RNAse A, and others. Therefore, Ni deficiency reduces urease activity, changes $\mathrm{N}$ assimilation, reduces SOD activity and decreases the elimination of superoxide free radicals (Fabiano et al., 2015; Matraszek et al., 2016). Another important role of $\mathrm{Ni}$ in plants is its contribution to phytoalexin synthesis, increasing plant resistance to various types of stress (Ahmad and Ashraf, 2011; Fabiano et al., 2015).
The DM yield of sorghum plants (Sorghum bicolor [L.] Moench) in an experiment applied $\mathrm{Ni}$ doses through soil sewage sludge at $280 \mathrm{mg} \mathrm{Ni} \mathrm{kg}^{-1}$ (Revoredo and Melo, 2006). These authors observed a difference in leaf and stem DM yield; leaves produced more DM than stems. When 746 $\mathrm{mg} \mathrm{Ni} \mathrm{kg}{ }^{-1}$ was added via sewage sludge, leaf DM yield was higher than for other parts of the plant. The effect of $\mathrm{Ni}$ doses in a sandy soil on tomato (Solanum lycopersicum L. var. lycopersicum) $105 \mathrm{~d}$ after transplanting reported an increase in the DM of roots, shoots, and fruits at a Ni dose of $30 \mathrm{mg} \mathrm{kg}^{-1}$ and an improvement in the visible aspects and biochemistry of the tomato plant (Gad et al., 2007). These evaluation parameters decreased at $\mathrm{Ni}$ doses of 45 and $60 \mathrm{mg} \mathrm{kg}^{-1}$.

An increase was observed in $\mathrm{Ni}$ concentration in all the cultivars and in all the analyzed plant organs to the extent that Ni doses applied to the soil increased (Table 2). The coefficients of the adjusted equations show that the highest $\mathrm{Ni}$ concentrations were observed in stem base DM weight followed by roots and shoots. 'Tanzania' has the highest Ni concentration in shoot and stem base DM weight

Table 2. Regression equations between the Ni concentration in the dry weight of tropical grasses $\left(\hat{\mathrm{y}}, \mathrm{mg} \mathrm{kg}^{-1} \mathrm{DW}\right)$ and Ni doses applied to the soil $\left(\mathrm{x}, \mathrm{mg} \mathrm{kg}^{-1}\right)$ and the critical range $\left(\mathrm{CR}, \mathrm{mg} \mathrm{kg}^{-1} \mathrm{DW}\right)$ corresponding to the recommended dose (RD) and critical toxicity dose (CTD) $90 \mathrm{~d}$ after the initial cut.

\begin{tabular}{|c|c|c|c|c|c|}
\hline Dry weight & Forage grasses & Regression equation & $\mathrm{R}^{2}$ & F test & $\mathrm{CR}$ \\
\hline Shoot & $\begin{array}{l}\text { Aruana } \\
\text { Tanzânia } \\
\text { Marandu } \\
\text { Xaraés } \\
\text { Basilisk }\end{array}$ & $\begin{array}{l}\hat{y}=0.77+1.0259 x^{0.5} \\
\hat{y}=1.48+0.2873 x \\
\hat{y}=1.45+0.1856 x \\
\hat{y}=1.50+1.6322 x^{0.5} \\
\hat{y}=0.10+0.2415 x\end{array}$ & $\begin{array}{l}0.98 \\
0.99 \\
0.99 \\
0.99 \\
0.99\end{array}$ & $\begin{array}{l}192.1 * * * \\
143.6 * * * \\
172.3 * * * \\
120.1 * * * \\
212.1 * * *\end{array}$ & $\begin{array}{r}3.4-8.0 \\
4.9-10.9 \\
6.9-12.5 \\
10.3-14.2 \\
6.7-17.0\end{array}$ \\
\hline Stem base & $\begin{array}{l}\text { Aruana } \\
\text { Tanzânia } \\
\text { Marandu } \\
\text { Xaraés } \\
\text { Basilisk }\end{array}$ & $\begin{array}{l}\hat{y}=0.62+1.3824 x^{0.5} \\
\hat{y}=1.86+0.6095 x \\
\hat{y}=2.65+0.4386 x \\
\hat{y}=1.70+3.0146 x^{0.5} \\
\hat{y}=0.11+0.5806 x\end{array}$ & $\begin{array}{l}0.94 \\
0.98 \\
0.99 \\
0.99 \\
0.97\end{array}$ & $\begin{array}{l}150.6 * * * \\
181.8 * * * \\
134.5 * * * \\
174.0 * * * \\
196.6 * * *\end{array}$ & $\begin{array}{r}4.1-10.4 \\
9.2-21.8 \\
15.6-28.8 \\
18.0-25.1 \\
15.9-40.8\end{array}$ \\
\hline Roots & $\begin{array}{l}\text { Aruana } \\
\text { Tanzânia } \\
\text { Marandu } \\
\text { Xaraés } \\
\text { Basilisk }\end{array}$ & $\begin{array}{l}\hat{y}=0.08+3.5736 x^{0.5} \\
\hat{y}=2.35+3.0251 x^{0.5} \\
\hat{y}=0.86+3.2676 x^{0.5} \\
\hat{y}=0.88+3.5423 x^{0.5} \\
\hat{y}=0.18+0.6253 x\end{array}$ & $\begin{array}{l}0.98 \\
0.99 \\
0.99 \\
0.99 \\
0.99\end{array}$ & $\begin{array}{l}181.4 * * * \\
140.8 * * * \\
171.8 * * * \\
129.7 * * * \\
157.8 * * *\end{array}$ & $\begin{array}{r}9.2-25.4 \\
12.9-19.6 \\
18.6-26.1 \\
20.0-28.4 \\
17.2-44.0\end{array}$ \\
\hline
\end{tabular}

\footnotetext{
$* * *$ Significant at $\mathrm{p}=0.001$
} 
followed by 'Basilisk' (Table 2). 'Aruana' has the lowest $\mathrm{Ni}$ concentration in shoot and stem base DM weight. As for root DM weight, 'Basilisk' has the highest Ni concentration followed by 'Aruana' and 'Tanzania' has the lowest $\mathrm{Ni}$ concentration in this organ.

A CR is observed when plant Ni concentrations are among the levels corresponding to RD and CTD in the soil. Levels below the $\mathrm{CR}$ indicate deficiency, while the plant exhibits toxicity above the CR. Most plants have a Ni CR between 0.05 and $10 \mathrm{mg} \mathrm{kg}^{-1} \mathrm{DM}$ (Chen et al., 2009) with levels higher than $10 \mathrm{mg} \mathrm{kg}^{-1}$ being toxic for most plants (Yusuf et al., 2011; Hussain et al., 2013; Matraszek et al., 2016).

The toxic Ni concentration in plants varies in relation to the degree of sensitivity or tolerance to the metal in the soil (Matraszek et al., 2016). On the other hand, the descending order of sensitivity or tolerance to $\mathrm{Ni}$ in the soil based on the CTD in shoot dry weight (Table 2) was 'Basilisk' > 'Xaraés' > 'Marandu' > 'Tanzania' > 'Aruana'; thus, tropical grasses are considered from sensitive to moderately tolerant to soil Ni (Yusuf et al., 2011; Hussain et al., 2013; Matraszek et al., 2016).

The Ni concentrations in plant organs are important mainly for information of zootechnical interest. If the $\mathrm{Ni}$ concentrations do not exceed the maximum allowed in leaves, animal consumption is permitted; this is combined with the environmental interest where plants could be grown in areas polluted with heavy metals. Values of Ni from 30 to $68 \mathrm{mg} \mathrm{kg}^{-1}$ were observed in leaves of leguminous crops and grasses used for feeding in the Soone Valley Salt Range in Pakistan (Ahmad et al., 2009); they were below $100 \mathrm{mg}$ $\mathrm{kg}^{-1}$, which is acceptable for ruminants (National Research Council, 2005).

Increasing $\mathrm{Ni}$ doses from 15 to $60 \mathrm{mg} \mathrm{kg}^{-1}$ in a sandy soil under field conditions had an effect on the tomato crop (Gad et al., 2007). These authors observed an increased Ni concentration in both leaves and fruits with increased soil $\mathrm{Ni}$ doses. The maximum $\mathrm{Ni}$ value reached in leaves was 42 $\mathrm{mg} \mathrm{kg}^{-1}$ and this value was $11.5 \mathrm{mg} \mathrm{kg}^{-1}$ in fruits. Netty et al.
(2013) compared the Ni concentration of roots and shoots in five plant species in soil contaminated $\left(94 \mathrm{mg} \mathrm{kg}^{-1}\right)$ by this metal. The species Sarcotheca celebica had the highest Ni concentration of $39.9 \mathrm{mg} \mathrm{kg}^{-1}$ in DM; in addition, it was the most tolerant plant to high soil Ni concentration. Tephrosia sp. had the lowest concentration $\left(1.9 \mathrm{mg} \mathrm{kg}^{-1}\right)$. In general, $\mathrm{Ni}$ concentration was higher in roots than in shoots because the Ni concentration in shoots did not differ among the studied species.

On average, the largest accumulations of $\mathrm{Ni}$ were observed in shoot DM followed by roots and minor accumulations were recorded in the stem base (Table 3). The greatest Ni accumulation was observed in 'Basilisk', shoot DM (325.7 ug pot $\left.^{-1}\right)$ followed by 'Tanzania' (185.6 $\mu \mathrm{g}$ $\left.\operatorname{pot}^{-1}\right)$, 'Aruana' (159.4 $\left.\mu \mathrm{g} \mathrm{pot}^{-1}\right)$, 'Marandu' (151.7 $\left.\mu \mathrm{g} \operatorname{pot}^{-1}\right)$, and finally 'Aruana' in root DM (125.5 $\left.\mathrm{g} \mathrm{pot}^{-1}\right)$. The dose corresponding to the highest accumulation of soil $\mathrm{Ni}$ was $120 \mathrm{mg} \mathrm{kg}^{-1}$ and was observed in 'Basilisk'. The lowest $\mathrm{Ni}$ accumulation was observed in stem base DM of 'Xaraés' according to the adjusted coefficients of the regression equations. This cultivar had little root DM buildup when compared to other cultivars. 'Aruana' also has a low Ni accumulation in stem base DM when compared to other cultivars.

'Xaraés' and 'Basilisk' had the lowest percentages of Ni accumulation in roots with $19 \%$ in both cultivars (Table 3 ). From the point of view of animal feeding, these would be the least recommended cultivars because the probability of animal contamination would be higher in this case. The highest percentage of $\mathrm{Ni}$ accumulation in root $\mathrm{DM}$ was observed in 'Aruana' (38\%), the most recommended forage for feeding in a contaminated area if this criterion were the only one being observed.

The cultivars that accumulate the highest percentages of $\mathrm{Ni}$ in shoot (cuts) DM in descending order were 'Xaraés' > 'Basilisk' > 'Tanzania' > 'Marandu' > 'Aruana' (Table 3). If only this criterion were followed, this would also be the recommended order for phytoremediation

Table 3. Regression equation between the $\mathrm{Ni}$ accumulations in the dry weight of tropical grasses $\left(\hat{\mathrm{y}}\right.$, $\mathrm{\mu g}$ pot $\left.^{-1}\right)$ and Ni doses applied to the soil $\left(\mathrm{x}, \mathrm{mg} \mathrm{kg}^{-1}\right)$ and the $\mathrm{Ni}$ dose $\left(\mathrm{DNi}_{\mathrm{Max}}, \mathrm{mg} \mathrm{kg}^{-1}\right)$ corresponding to the maximum $\mathrm{Ni}$ accumulation $\left(\mathrm{Ni}_{\mathrm{Max}}, \mathrm{\mu g} \mathrm{pot}^{-1}\right) 90 \mathrm{~d}^{-1}$ after the initial cut.

\begin{tabular}{|c|c|c|c|c|c|c|}
\hline Dry weight & Forage grasses & Regression equation & $\mathrm{R}^{2}$ & F test & $\mathrm{DNi}_{\mathrm{Max}}$ & $\mathrm{Ni}_{\mathrm{Max}}$ \\
\hline \multirow[t]{5}{*}{ Shoot } & Aruana & $\hat{y}=10.89+3.1776 x-0.0170 x^{2}$ & 0.99 & $196.0 * * *$ & 93.5 & 159.4 \\
\hline & Tanzânia & $\hat{y}=9.23+4.0547 x-0.0233 x^{2}$ & 0.99 & $154.8 * * *$ & 87.0 & 185.6 \\
\hline & Marandu & $\hat{y}=7.83+3.8383 x-0.0256 x^{2}$ & 0.92 & $148.2 * * *$ & 75.0 & 151.7 \\
\hline & Xaraés & $\hat{y}=2.50+2.3742 x-0.0166 x^{2}$ & 0.97 & $125.1 * * *$ & 71.5 & 87.4 \\
\hline & Basilisk & $\hat{y}=15.80+2.5825 x$ & 0.99 & $172.8^{* * *}$ & 120.0 & 325.7 \\
\hline \multirow[t]{5}{*}{ Stem base } & Aruana & $\hat{y}=2.57+1.0657 x-0.0063 x^{2}$ & 0.98 & $161.8 * * *$ & 84.6 & 47.6 \\
\hline & Tanzânia & $\hat{y}=5.70+13.0770 \times 0.5-0.5456 x$ & 0.99 & $118.9 * * *$ & 39.5 & 66.3 \\
\hline & Marandu & $\hat{y}=1.53+2.0158 x-0.0134 x^{2}$ & 0.93 & $142.2 * * *$ & 75.2 & 77.3 \\
\hline & Xaraés & $\hat{y}=0.15+0.4839 x-0.0031 x^{2}$ & 0.93 & $129.9 * * *$ & 75.7 & 17.3 \\
\hline & Basilisk & $\hat{y}=7.56+0.6572 x$ & 0.98 & $173.6^{* * * *}$ & 120.0 & 86.4 \\
\hline \multirow[t]{5}{*}{ Roots } & Aruana & $\hat{y}=5.10+2.9846 x-0.0185 x^{2}$ & 0.99 & $191.8 * * *$ & 80.7 & 125.5 \\
\hline & Tanzânia & $\hat{y}=9.89+2.4592 x-0.0203 x^{2}$ & 0.87 & $180.2 * * *$ & 60.6 & 84.4 \\
\hline & Marandu & $\hat{y}=1.93+2.4806 x-0.0192 x^{2}$ & 0.92 & $124.4 * * *$ & 64.6 & 82.1 \\
\hline & Xaraés & $\hat{y}=0.35+0.6801 x-0.0048 x^{2}$ & 0.99 & $158.8^{* * *}$ & 70.8 & 24.4 \\
\hline & Basilisk & $\hat{y}=3.83+2.5201 x-0.0171 x^{2}$ & 0.95 & $196.2 * * *$ & 73.7 & 96.7 \\
\hline
\end{tabular}

\footnotetext{
$* * *$ Significant at $\mathrm{p}=0.001$.
} 
of $\mathrm{Ni}$-contaminated or polluted areas. The highest $\mathrm{Ni}$ accumulation percentage was concentrated in shoots for all cultivars with a more balanced distribution only in 'Aruana'. This heavy metal percentage distribution between the organs of the plant reflects its mobility and more clearly ensures the purpose of using cultivars for phytoremediation processes of contaminated areas.

When comparing soil $\mathrm{Ni}$ accumulation in doses of 50 and $100 \mathrm{mg} \mathrm{kg}^{-1}$ by Bermuda grass (Cynodon dactylon) and fescue grass (Festuca arundinacea) in roots and shoots, Soleimani et al. (2009) observed that fescue grass accumulated more $\mathrm{Ni}$ in roots than Bermuda grass. Bermuda grass accumulated more $\mathrm{Ni}$ in shoots than the fescue grass in at least one of the alkaline soils of medium texture. The largest accumulations were recorded in fescue grass roots ( 25 to $30 \mathrm{mg} \mathrm{kg}^{-1}$ ) and also in the shoot of Bermuda grass (25 to $30 \mathrm{mg} \mathrm{kg}^{-1}$ ). These authors concluded that these species cannot be considered as Ni hyperaccumulators.

Heavy metal accumulation capacity varies widely among plant species, growth stage, cultivation conditions, Ni concentration, and exposure time (Chen et al., 2009). For three plant species, Spinacia oleracea, Amaranthus oleraceus and Amaranthus tricolor growing in soil with total $\mathrm{Ni}$ concentration of $14.4 \mathrm{mg} \mathrm{kg}^{-1}$, distinct accumulations were observed for the species with $\mathrm{Ni}$ values from 3 to $6 \mathrm{mg} \mathrm{kg}^{-1} \mathrm{DM}$ over a period of $50 \mathrm{~d}$ after planting (Naser et al., 2011). In soils with high Ni concentrations, such as ultramafic soils, plants with high tolerance and heavy metal accumulation capacity (hyperaccumulator) can accumulate more than the cultivars tested in this experiment. The Ni concentration of Thlaspi japonicum, a Ni hyperaccumulator plant, $\mathrm{Ni}$ concentration was observed up to $1000 \mathrm{mg} \mathrm{kg}^{-1} \mathrm{DM}$ in a soil with $1553 \mathrm{mg} \mathrm{kg}^{-1}$ total concentration of the element (Mizuno et al., 2005).
The Ni concentrations obtained from the soil by Mehlich-1, DTPA at pH 7.3, USEPA 3051, and USEPA 3052 extraction, according to the adjusted regression equations, increased linearly with the increase of soil Ni doses applied to the soil (Table 4); a higher Ni concentration was noted in the soil extracted by the total extraction method (USEPA 3052) followed by the USEPA 3051 method, Mehlich-1, and DTPA pH 7.3. The highest soil Ni concentration extracted by the USEPA 3052 method was because this extractor is composed of a mixture of concentrated acids $\left(\mathrm{H}_{2} \mathrm{O}_{2}+\mathrm{HNO}_{3}\right.$ $+\mathrm{HF}+\mathrm{H}_{3} \mathrm{BO}_{3}$ ) that can recover almost all the $\mathrm{Ni}$ applied to the soil; it has the ability to attack all the ways that the metal has to solubilize and extract.

The reference levels for heavy metals in the soil are commonly assigned by extraction methods (USEPA 3052 and 3051), for example, in the tables of the São Paulo State Environmental Agency (2005). The DTPA pH 7.3 chelating extractor is used as an official extractor in laboratory routines for cationic micronutrients in the state of São Paulo, while the Mehlich-1 method is used in the state of Minas Gerais.

The highest concentration obtained from the CR corresponding to CTD with the total extractor (USEPA 3051 and 3052) was higher than the value recommended by the São Paulo State Environmental Agency (2005) and the National Environmental Council of Brazil (2009) to ensure soil quality and prevent problems with food grown in contaminated soils for all the studied tropical grass cultivars (Table 4).

The soil quality reference values proposed by the São Paulo State Environmental Agency (2005) and the National Environmental Council of Brazil (2009) cannot be compared to the Mehlich-1 and DTPA at pH 7.3 extractors because the methods used were adjusted to measure

Table 4. Regression equations between the Ni concentration in soil extracted using the Mehlich ${ }^{-1}$, DTPA, USEPA 3051, and USEPA 3052 methods $\left(\hat{\mathrm{y}}, \mathrm{mg} \mathrm{kg}^{-1}\right)$ and $\mathrm{Ni}$ doses applied to the soil $\left(\mathrm{x}, \mathrm{mg} \mathrm{kg}^{-1}\right)$ and the critical range $\left(\mathrm{CR}, \mathrm{mg} \mathrm{kg}^{-1}\right) \mathrm{corresponding}$ to the recommended dose (RD) and critical toxicity dose (CTD) $90 \mathrm{~d}$ after the initial cut.

\begin{tabular}{|c|c|c|c|c|c|}
\hline Method & Forage grasses & Regression equation & $\mathrm{R}^{2}$ & F test & $\mathrm{CR}$ \\
\hline Mehlich-1 & $\begin{array}{l}\text { Aruana } \\
\text { Tanzânia } \\
\text { Marandu } \\
\text { Xaraés } \\
\text { Basilisk }\end{array}$ & $\begin{array}{l}\hat{y}=0.17+0.4514 x \\
\hat{y}=0.15+0.4714 x \\
\hat{y}=0.14+0.4631 x \\
\hat{y}=0.19+0.4224 x \\
\hat{y}=0.10+0.4341 x\end{array}$ & $\begin{array}{l}0.99 \\
0.99 \\
0.99 \\
0.99 \\
0.99\end{array}$ & $\begin{array}{l}145.8 * * * \\
108.7 * * * \\
146.2 * * * \\
123.1 * * * \\
137.8 * * *\end{array}$ & $\begin{array}{r}3.1-22.8 \\
5.8-15.6 \\
13.8-27.8 \\
12.5-25.7 \\
11.9-30.5\end{array}$ \\
\hline DTPA & $\begin{array}{l}\text { Aruana } \\
\text { Tanzânia } \\
\text { Marandu } \\
\text { Xaraés } \\
\text { Basilisk }\end{array}$ & $\begin{array}{l}\hat{y}=0.08+0.2866 x \\
\hat{y}=0.05+0.3360 x \\
\hat{y}=0.07+0.3059 x \\
\hat{y}=0.05+0.2909 x \\
\hat{y}=0.03+0.3170 x\end{array}$ & $\begin{array}{l}0.99 \\
0.99 \\
0.99 \\
0.99 \\
0.99\end{array}$ & $\begin{array}{l}188.4 * * * \\
175.1 * * * \\
111.2 * * * \\
194.7 * * * \\
188.7 * * *\end{array}$ & $\begin{array}{l}1.9-14.4 \\
4.1-11.0 \\
9.1-18.3 \\
8.6-17.6 \\
8.7-22.2\end{array}$ \\
\hline USEPA 3051 & $\begin{array}{l}\text { Aruana } \\
\text { Tanzânia } \\
\text { Marandu } \\
\text { Xaraés } \\
\text { Basilisk }\end{array}$ & $\begin{array}{l}\hat{y}=0.01+0.7744 x \\
\hat{y}=0.01+0.8714 x \\
\hat{y}=0.01+0.7773 x \\
\hat{y}=0.01+0.7702 x \\
\hat{y}=0.01+0.7687 x\end{array}$ & $\begin{array}{l}0.99 \\
0.99 \\
0.99 \\
0.99 \\
0.99\end{array}$ & $\begin{array}{l}184.7 * * * \\
122.8 * * * \\
158.6 * * * \\
115.3 * * * \\
108.6 * * *\end{array}$ & $\begin{array}{r}5.0-38.8 \\
10.5-28.5 \\
22.9-46.4 \\
22.5-46.5 \\
21.0-53.8\end{array}$ \\
\hline USEPA 3052 & $\begin{array}{l}\text { Aruana } \\
\text { Tanzânia } \\
\text { Marandu } \\
\text { Xaraés } \\
\text { Basilisk }\end{array}$ & $\begin{array}{l}\hat{y}=0.01+0.8704 x \\
\hat{y}=0.01+0.9965 x \\
\hat{y}=0.01+0.8238 x \\
\hat{y}=0.01+0.9186 x \\
\hat{y}=0.01+0.8566 x\end{array}$ & $\begin{array}{l}0.96 \\
0.99 \\
0.96 \\
0.98 \\
0.97\end{array}$ & $\begin{array}{l}132.8 * * * \\
123.9 * * * \\
164.8 * * * \\
142.5 * * * \\
129.2 * * *\end{array}$ & $\begin{array}{r}5.6-43.6 \\
12.0-32.6 \\
24.3-49.2 \\
26.9-55.4 \\
23.4-60.0\end{array}$ \\
\hline
\end{tabular}

\footnotetext{
$* * *$ Significant at $\mathrm{p}=0.001$.
} 
available levels for plants rather than total levels (Rodak et al., 2015). Therefore, there are no ranges and critical values in agricultural or natural soils regarding available $\mathrm{Ni}$ concentrations (Mehlich-1 and DTPA), demonstrating the need to define them as in the present work (Table 4).

The bioavailability of heavy metals in the soil depends on several factors intrinsic to the soil, such as $\mathrm{pH}$, organic matter concentration, clay concentration, and redox potential. Tchounwou et al. (2012) reported the effect of some of these factors on various cationic metals, such as $\mathrm{Ni}, \mathrm{Zn}, \mathrm{Pb}, \mathrm{Cu}$, and $\mathrm{Cd}$, and concluded that the variation in these factors modifies the availability of heavy metals in the soil. Therefore, $\mathrm{Ni}$ availability for plants is subjected to the interaction of these soil factors and displays a different behavior from the one observed in the nutrient solution.

Correlations were positive between $\mathrm{Ni}$ accumulation in tropical grass cultivars and $\mathrm{Ni}$ concentrations extracted by the studied chemical extractors (Figure 2). All extractors can be considered good for predicting $\mathrm{Ni}$ availability in tropical grasses. The Mehlich-1 and DTPA pH 7.3 extractors correlate well with plant $\mathrm{Ni}$ accumulation just as the USEPA 3051 and 3052 extractors after a 90-d period when $\mathrm{Ni}$ was applied to the soil; the latter two extractors are used worldwide as a reference for quality in relation to heavy metal concentration in the soil.

There was a high positive correlation $(r=0.96)$ between Ni concentrations extracted by DTPA and Ni concentration in leaves; it was high in common bean (Phaseolus vulgaris), showing a high efficiency of the extractor to estimate $\mathrm{Ni}$ bioavailability (Berton et al., 2006). Soleimani et al. (2009) found a high positive correlation $(\mathrm{r}=0.94)$ between $\mathrm{Ni}$ accumulation in Bermuda grass and fescue grass and $\mathrm{Ni}$ extracted by DTPA, showing a direct relationship between Ni extracted from the soil and the uptake of this metal by these grasses. Chang et al. (2014) already observed in Entisols, Inceptisols, Andisols, Vertisols, Alfisols, Ultisols, and Oxisols that the $\mathrm{HCl}$ solution $0.1 \mathrm{~mol} \mathrm{~L}^{-1}$ and DTPA pH 7.3 extractors were efficient in predicting $\mathrm{Ni}$ availability. These results suggest that $\mathrm{Ni}$ uptake is particular to each plant and depends on genetic and environmental factors, and this leads to the need for specific extractor studies for each plant and soil type.

\section{CONCLUSIONS}

Tropical grasses showed a positive response to the application of nickel (Ni) doses. The order of decreasing tolerance of tropical grasses to $\mathrm{Ni}$ soil was Urochloa decumbens 'Basilisk' > Urochloa brizantha 'Xaraés' > Urochloa brizantha 'Marandu' > Megathyrsus maximus 'Tanzania'> Megathyrsus maximus 'Aruana' based on the critical toxicity dose. Nickel concentration and accumulation increased with increasing soil $\mathrm{Ni}$ doses in all tropical grasses. The Mehlich 1, DTPA, USEPA 3051, and USEPA $3052 \mathrm{Ni}$ extraction methods in the soil are efficient to diagnose $\mathrm{Ni}$ availability in tropical grasses.

\section{ACKNOWLEDGEMENTS}

The authors appreciate the support from the Brazilian agencies $\mathrm{CNPq}$ and Fapemig; Capes provided a graduate student stipend. The Department of Soil Science, ESALQ, University of São Paulo provided the laboratory analysis of soil samples. The Federal University of the Jequitinhonha and Mucuri (UFVJM) provided the infrastructure needed to conduct this study.

\section{REFERENCES}

Ahmad, M.S.A., and Ashraf, M. 2011. Essential roles and hazardous effects of nickel in plants. Reviews of Environmental Contamination and Toxicology 214:125-167. doi:10.1007/9781-4614-0668-6_6.

Figure 2. Relationship between Ni accumulated in the dry matter of tropical grass shoots and extraction methods (Mehlich-1, DTPA, USEPA 3051, and USEPA 3052) $90 \mathrm{~d}$ after the initial cut.

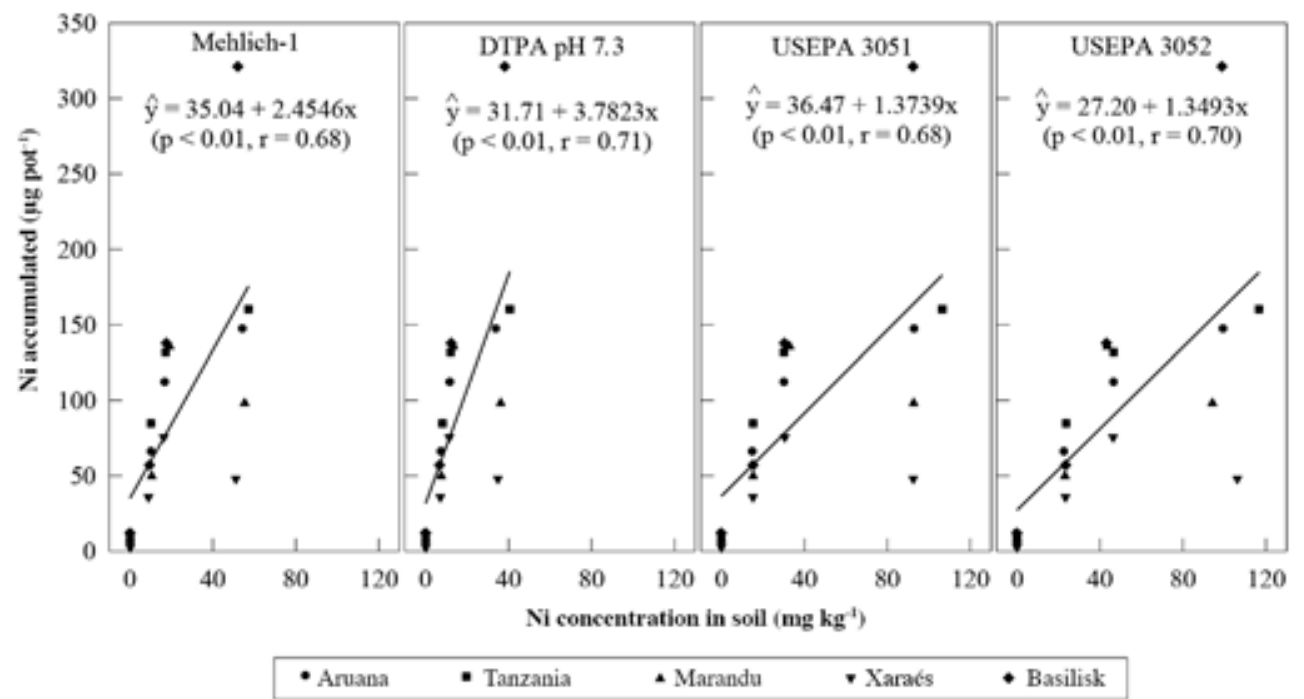


Ahmad, K., Khan, Z.I., Ashraf, M., Vallem, E.E., Shah, Z.A., and McDowell, L.R. 2009. Determination of forage concentrations of lead, nickel and chromium in relation to the requirements of grazing ruminants in the Salt Range, Paquistan. Pakistan Journal Botany 41:61-65.

Berton, R.S., Pires, A.M.M., Andrade, S.A.L., Abreu, C.A., Ambrosano, E.J., and Silveira, A.P.D. 2006. Nickel toxicity in common bean plants and effects on soil microbiota. Pesquisa Agropecuária Brasileira 41:1305-1312. doi:10.1590/S0100204X2006000800014

Chang, Y.T., Hseu, Z.Y., and Zehetner, F. 2014. Evaluation of phytoavailability of heavy metals to Chinese cabbage (Brassica chinensis L.) in rural soils. The Scientific World Journal 2014:110. doi:10.1155/2014/309396.

Chen, C., Huang, D., and Liu, J. 2009. Functions and toxicity of nickel in plants: Recent advances and future prospects. Clean 37:304-313. doi:10.1002/clen.200800199.

Chen, Q., and Wong, J.W.C. 2006. Growth of Agropyron elongatum in a simulated nickel contaminated soil with lime stabilization. Science of the Total Environment 366:448-455. doi:10.1016/j.scitotenv.2005.01.022.

Embrapa. 1997. Manual for methods of soil analysis. $2^{\text {nd }}$ ed. National Service for Soil Survey and Soil Conservation. Empresa Brasileira de Pesquisa Agropecuária (Embrapa), Rio de Janeiro, Brazil.

Fabiano, C.C., Tezotto, T., Favarin, J.L., Polacco, J.C., and Mazzafera, P. 2015. Essentiality of nickel in plants: a role in plant stresses. Frontiers in Plant Science 6:754-758. doi:10.3389/fpls.2015.00754.

Gad, N., El-Sherifel, M.H., and Gereedly, N.H.M. 2007. Influence of nickel on some physiological aspects of tomato plants. Australian Journal of Basic and Applied Sciences 1:286-293.

Hair, J.F.J., Black, W.C., Babin, B.J., and Anderson, R.E. 2009. Multivariate data analysis. $7^{\text {th }}$ ed. Prentice Hall, New Jersey, USA.

Hussain, M.B., Ali, S., Azam, A., Hina, S., Ahsan, M., Farooq, B.A., et al. 2013. Morphological, physiological and biochemical responses of plants to nickel stress: A review. African Journal of Agricultural Research 8:1596-1602. doi:10.5897/AJAR12.407.

Jabeen, R., Ahmad, A., and Iqbal, M. 2009. Phytoremediation of heavy metals: physiological and molecular mechanisms. The Botanical Review 75:339-364. doi:10.1007/s12229-009-9036-x.

Kovácik, J., Klejdus, B., Kaduková, J., and Backor, M. 2009. Physiology of Matricaria chamomilla exposed to nickel excess. Ecotoxicology and Environmental Safety 72:603-609. doi:10.1016/j.ecoenv.2007.12.013.

Leitenmaier, B., and Küpper, H. 2013. Compartmentation and complexation of metals in hyperaccumulators plants. Frontiers in Plant Science 4:374-386. doi:10.3389/fpts.2013.00374.

López, M.Á., and Magnitski, S. 2011. Nickel: The last of the essential micronutrients. Agronomía Colombiana 29:49-56.

Matraszek, R., Hawrylak-Nowak, B., Chwil, S., and Chwil, M. 2016. Macronutrient composition of nickel-treated wheat under different sulfur concentrations in the nutrient solution. Environmental Science and Pollution Research 23:5902-5914. doi:10.1007/s11356-015-5823-6.

Mizuno, T., Obata, H., Horie, K., Nosaka, S., and Mizuno, N. 2005. Comparison of $\mathrm{Ni} / \mathrm{Zn}$ accumulation ability of Thlaspi japonicum from three different areas in Hokkaido. Soil Science and Plant Nutrition 51:589-594. doi:10.111/j.1747-0765.2005. tb00069.x.
Nascimento, S.S., Silva, E.B., Alleoni, L.R.F., Grazziotti, P.H., Fonseca, F.G., and Nardis, B.O. 2014. Availability and accumulation of lead for forage grasses in contaminated soil. Journal of Soil Science and Plant Nutrition 14:783-802. doi:10.4067/S0718-95162014005000063.

Naser, H.M., Sultana, S., Mahmud, N.U., Gomes, R., and Noor, S. 2011. Heavy metal levels in vegetables with growth stage and plant species variations. Bangladesh Journal of Agricultural Research 36:563-574. doi:10.3329/bjar.v36i4.11743.

National Environmental Council of Brazil. 2009. Resolução $n^{\circ} 420 / 2009$. It provides criteria and guiding values of soil quality for the presence of chemical substances and establishes guidelines for the environmental management of areas contaminated by these substances as a result of anthropic activities. Available at http://www.mma.gov.br/port/conama/ legiabre.cfm?codlegi=620 (accessed May 2013).

National Research Council. 2005. Mineral tolerance of domestic animals. Second revised edition. 510 p. The National Academies Press, Washington, D.C., USA.

Netty, S., Wardiyati, T., Maghfoer, M.D., and Handayanto, E. 2013. Bioaccumulation of nickel by five wild plant species on nickel contaminated soil. Journal of Engineering 3:1-6.

Revoredo, M.D., and Melo, W.J. 2006. Availability of nickel in soil treated with sewage sludge and cultivated with sorghum. Bragantia 65:679-685. doi:10.1590/S000687052006000400019.

Rodak, B.W., Moraes, M.F., Pascoalino, J.A.L., Oliveira Junior, A., Castro, C., and Pauletti, V. 2015. Methods to quantify nickel in soils and plant tissues. Revista Brasileira de Ciência do Solo 39:788-793. doi:10.1590/01000683rbcs20140542.

São Paulo State Environmental Agency. 2005. Report on standard values for soils and groundwater in the São Paulo State. Companhia Ambiental do Estado de São Paulo (Cetesb), São Paulo, Brazil. Available at http://www.cetesb.sp.gov.br/Solo/ relatorios/tabela_valores_2005.pdf (accessed April 2013).

Soil Survey Staff. 2010. Soil taxonomy: Keys to soil taxonomy. $11^{\text {th }}$ ed. Department of Agriculture, Natural Resources and Conservation Services, Washington, D.C., USA.

Soleimani, M., M.A. Hajabbasi, M. Afyuni, A.H. Charkhabi, and H. Shariatmadari. 2009. Bioaccumulation of nickel and lead by bermuda grass (Cynodon dactylon) and tall fescue (Festuca arundinacea) from two contaminated soils. Caspian Journal of Environmental Sciences 7:59-70.

Tchounwou, P.B., Yedjou, C.G., Patlolla, A.K., and Sutton, D.J. 2012. Heavy metals toxicity and the environment. Molecular, Clinical and Environmental Toxicology 101:133-164. doi:10.1007/978-3-7643-8340-4_6

USEPA. 2007. Microwave assisted acid digestion of sediments, sludges, soils and oils. Method 3052-SW-846, 1994. United States Environmental Protection Agency (USEPA), Washington, D.C., USA. Available at https://www.epa.gov/sites/production/ files/2015-12/documents/3051a.pdf (accessed March 2013).

Yusuf, M., Fariduddin, Q., Hayat, S., and Ahmad, A. 2011. Nickel: an overview of uptake, essentiality and toxicity in plants. Bulletin of Environmental Contamination and Toxicology 86:117. doi:10.1007/s00128-010-0171-1.

Zhang, M.K., Liu, Z.Y., and Wang, H. 2010. Use of single extraction methods to predict bioavailability of heavy metals in polluted soils to rice. Communications in Soil Science and Plant Analysis 41:820-831. doi:10.1080/00103621003592341. 